\title{
Concentration in the International Construction Market
}

Kunhui YE ${ }^{1}$, Weisheng $\mathrm{LU}^{2}$ and Weiyan JIANG ${ }^{1}$

\section{Abstract}

With the involvement of an increasing number of contractors in the international construction market, venturing overseas has been fraught with fierce competition and considerable uncertainties. This underscores the importance of examining the extent to which the intensity of competition (IoC) for international construction business is moderate. Concentration is a conventional IoC measure. By synthesising four major concentration methods including concentration ratio, entropy, Gini coefficient and Herfindahl index, a new model for measuring moderate $\mathrm{IoC}$ is thus proposed. Using the 28 years ENR-based data of the top 225 international contractors (TIC 225) into the proposed model, the IoC for international construction business is found moderate, if the magnitude of the market shares occupied by the top four international contractors is 0.2735. The finding does revise a popular view that international construction competition has been intensifying only since 2002. It is implied that the proposed model favours a better understanding of competition characteristics in the international construction market and provides new insights into the theories about concentration.

\section{Keywords}

International construction market, Business concentration, Intensity of competition, Moderate competition

\footnotetext{
${ }^{1}$ Faculty of Construction Management and Real Estate, Chongqing University, P.R. China

${ }^{2}$ Department of Real Estate and Construction, The University of Hong Kong, Pokfulam, Hong Kong
} 


\section{INTRODUCTION}

The $21^{\text {st }}$ century is characterised by advanced technology, fast transportation, convenient communication, integrated market, and trade liberalisation. These new characteristics have accelerated the internationalisation of construction businesses, and few contactors find that they can be exempt from this trend (Raftery et al. 1998; Loosemore 1999; Korkmaz and Messener 2007). On the one hand, many construction firms adopt venturing overseas as a major strategy to ensure continued growth. They make due response to business competition in cross-border markets. On the other hand, they have to struggle against foreign rivals in their domestic markets. The construction business is nowadays both a local and an international practice.

With the increasing internationalisation of construction market, there is a popular view that the intensity of competition (IoC) has been ascending and the international market has consequently much volatility. For instance, Ofori (2003) opined that involving contractors from China, South America, South-East Asia and Africa, the international market will be more competitive. Low et al. (2004) disclosed that as a result of intense competition, the international involvement of top British contractors has declined from a peak in 1996, whilst there has been an increasing presence of Chinese contractors in the international arena. Although competition in construction market worldwide has been an all-pervading phenomenon, it is considered that a moderate IoC deserves attention. This is because little or no competition is not good to the effectiveness and efficiency of the deployment of construction resources, whilst over competition can result in serious market failure (Ball et al. 2000; Akintoye and Skitmore 1991).

The IoC has been measured in a number of ways typically including concentration, 
market mobility and market instability (Bajo and Salas 2002; Barla 1999). Among the existing approaches, concentration is a conventional instrument that measures competition intensity by quantifying the extent to which market shares are distributed among incumbent (Egghe 2005; Bajo and Salas 2002). The rationale behind the concentration-based measurement is that a high degree of concentration in an industry conveys an image of weak competition, whilst those industries wherein numerous businesses have parallel market shares are deemed as highly competitive (Boone 2001). Concentration is thus an indirect measure of competition intensity.

Employing concentration approaches to measure competition intensity is prevalent in the area of construction management and economics. Chiang et al. (2001) found that construction business in the building sector was less concentrated than that in the civil engineering sector in Hong Kong. McCloughan (2004) illustrated little concentration phenomenon in the British construction market. There are still other related studies addressing parallel findings that construction firms appear to have equivalent market powers, construction business is unconcentrated, and construction market is of fierce competition (Langford and Male 2001; Wang 2004). Notwithstanding considerable research devoted to the subject of competition intensity, few efforts have been put in researching moderate $\mathrm{IoC}$ in the international construction market. As assumed earlier, little competition or over competition can both bring about market failure, while a moderate IoC is good for the long-run development of the international construction market.

The purpose of this study is therefore to examine what moderate $\mathrm{IoC}$ is in the international construction market from the perspective of market concentration. The study offers new insights into international construction competition. Through such an 
examination, it is possible for international contractors to gauge competition pressure, and thus appropriate competitive strategies can be devised to address this competition. The paper decomposes into four parts. First, previous theories about market concentration are reviewed critically. In the following "methods" section, a new concentration approach is proposed based on the critical review. Data collection methods are introduced. Then it moves on to the data analyses and discussions of IoC in the international construction arena. Lastly, conclusions are drawn.

\section{MEASURES OF CONCENTRATION}

\section{Theories on concentration}

Concentration theories are an important part of the structure-conduct-performance paradigm in the discipline of industrial economics (Bird 1999; McCloughan 2004). The concern about concentration can be traced back as early as to the development of the theories of imperfect and monopolistic competition in the 1930s (Utton 1970). Since that, substantial research has been conducted to investigate the application of concentration theories in different industrial sectors.

Research has pinpointed the impact of concentration on various aspects of the structureconduct-performance paradigm, e.g. industrial profitability (Bonardi 2001), advertising (Shepherd and Shepherd 2004), innovation (Shrieves 1978; Boone 2001), pricing (Bonanno and Haworth 1998), differentiation (Shepherd and Shepherd 2004), specialisation (George 1972), diversification (Carlton and Perloff 2005), market entry barriers (Lipczynski and Wilson 2001), industrial wage (Haworth and Reuther 1978), and competition policies (Wang 2004). The measurement of concentration supports governmental decision-making on deterring any collusive or anticompetitive behaviours 
(Bird 1999).

On the other hand, concentration is determined by multiple factors including business diversity (Miller 1969), market entry barriers (Wenders 1971), market growth (Shepherd 1964) and market size (Neumann et al. 2001). It seems that the term concentration has become multidimensional, referred to the concentration of economic power, market power, oligopoly power, competition intensity and market efficiency. The multidimensional nature complicates the measurement of concentration.

\section{Concentration measures}

There are four dominant approaches to measuring concentration, namely, concentration ratio $\left(C R_{\boldsymbol{n}}\right)$, Herfindahl Index $\left(H I_{n}\right)$, entropy $(E N)$, and Gini coefficient $(G I N I)$. More introduction about these four concentration measures is summarised in Table 1. It can be seen from the column "model" of Table 1 that the calculation of the four concentration indexes is mainly based on firm i's market share $\left(S_{i}\right)$ and firm number $(n)$.

\section{$\leq<$ Insert Table 1 here $>>$}

Concentration ratio $\left(\mathrm{CR}_{n}\right)$ can be calculated as the percentage of the outputs occupied by the $n$ largest firms in relation to a given market. The extremes of $C R_{n}$ values are zero and one, representing perfect competition and little competition (monopoly) respectively. For example, van Kranenburg (2002) employed the measure $C R_{4}$ to address the status of market competition, and suggested that the industry is highly competitive if $C R_{4}$ is close to 0 . On the contrary, it means that the market is close to a monopoly when $C R_{4}$ is near to 1. It is one of the most commonly used concentration measures because of the relatively 
easier collection of data in terms of the largest $n$ (normally 4 or 8 ) companies and their market shares.

Although $\mathrm{CR}_{n}$ has many applications, criticism on $\mathrm{CR}_{\boldsymbol{n}}$ is largely focused on its two major inadequacies. First, the measure only accounts for the market powers owned by a few largest firms without account of the other firms in the market. Second, the equalweight setting in the $\mathrm{CR}_{\mathrm{n}}$ construct oversimplifies the substantial difference in market powers of the investigated $n$ largest firms. As an alternative, Herfindahl index (HI) envisages the presence of all firms by weighting each according to their relative market shares. As can be seen from Table 1, HI ranges from zero (perfect competition) to one (little competition). An increase in HI value equals a decrease in competition intensity.

Entropy (EN) measures the uncertainty/probability of a random variable in information theory (Yu 2000). The process of business competition is so interactive, complex and dynamic that not all competitors can always outperform their counterparts (Bengtsson 1998). Therefore, concentration of market shares as a consequence of business competition appears to be an accident. Many researchers have thus used EN to reflect the process of business rivalry, the distribution of marker powers among incumbent and the corresponding status of market competition (Horowitz and Horowitz 1968). The higher the IoC level, the lower the probability that firms can outdo their competitors. Entropy and industrial concentration are inversely related.

Gini coefficient (GINI) is directly linked to the well-known Lorenz curve that is defined as a ratio with values varying between zero and one in describing the extent to which the distribution of income, wealth and business. GINI can be derived by quantifying the deviation of the distribution of market shares held by all firms from a current status to the 
equal situation where each firm has identical market share (Egghe 2005; Baldwin and Gorecki 1994). As a general rule, the decrease in GINI indicates the approach of the market to the equal situation and a higher intensity of competition, whilst a larger coefficient mirrors a more unequal distribution and a lower IoC accordingly.

The merits and demerits of concentration measures have long been debated in previous studies. For instance, Davies (1979) developed an Iso-concentration approach to unveil the close similarities between the above four measures. Kwoka (1981) illustrated that the choice of concentration measures does matter to a large extent. Bailey and Boyle (1971) claimed that few concentration indexes are superior to others, while Hall and Tideman (1967) asserted that the measure HI is more effective. The debate on concentration measures has not pinpointed a good way for understanding moderate IoC, but it does suggest using an individual measure for the investigation of market concentration may not be robust. There is a need for a new model with greater robustness to measure market concentration and in turn to inform moderate IoC.

\section{RESEARCH METHODS}

\section{Proposing a new model for measuring moderate IoC}

The inadequacy of single measure (e.g. $C R_{n}, H I_{n}, E N$, and GINI) for the investigation of market concentration necessitates the exploration of an improved concentration measure, which ideally could eliminate the demerits of previous studies while keep their merits. Moreover, the new model should inform moderate $\mathrm{IoC}$ in the international construction market as concerned in this study. According to the definitions shown in Table 1, the decrease in EN value suggests that the incumbent are able to win business competition with higher probabilities, thus the market is more attractive to potential competitors. 
Meanwhile, the decrease in EN value presents an increase in the dominance of a few largest firms as well as the level of market inequality that can be measured by GINI. This further enables greater market entry barriers posed by the largest firms to impede the entrance of potential competitors. Researchers have pointed out that the occurrence of greater entry barriers can force the market away from its contestable status (Bain 1956; Bengtsson 1998). Therefore, the lower the market entry barriers are, the better the market is, and thus the lower the GINI should be. This interactive process signals the potential intersection of EN and GINI where the desirable IoC (or concentration status) can be recorded as shown in Figure 1.

\section{$\leq<$ Insert Figure 1 here $>>$}

As discussed above, the measure $\mathrm{HI}$ is better than $\mathrm{CR}_{\mathrm{n}}$ in reflecting competition intensity, but the difficulty of collecting data for HI undermines the applicability to construction market. While on the other hand $\mathrm{CR}_{\mathrm{n}}$ is an acceptable measure for concentration and it is an easy-to-calculate indicator of concentration with statistics usually available in many governmental periodical compilations. It is therefore the intent of this research to use $\mathrm{CR}_{\mathrm{n}}$ to construct EN, GINI, and HI. This is possible because the above discussion on the four concentration measures favours the recognition of conceptual relationships between $\mathrm{EN}, \mathrm{HI}, \mathrm{GINI}$ and $\mathrm{CR}_{\mathrm{n}}$ as shown in Table 2. In order for them to join in the calculation, different concentration measures with different ranges need to be normalized. Formula (1) to (3) serve this purpose. GINI index needs no normalisation as its range is $(0,1)$ already.

Normalised Herfindahl index (HI):

$$
\mathrm{NHI}=(\mathrm{HI}-1 / \mathrm{n}) /(1-1 / \mathrm{n})=(\mathrm{HI}-1 / 225) /(1-1 / 225)
$$


Normalised concentration ratio $\left(\mathrm{CR}_{4}\right)$ :

$$
\mathrm{NCR}_{4}=\left(\mathrm{CR}_{4}-4 / \mathrm{n}\right) /(1-4 / \mathrm{n})=\left(\mathrm{CR}_{4}-4 / 225\right) /(1-4 / 225)
$$

Normalised entropy index (EN):

$$
\mathrm{NEN}=(\mathrm{EN}-0) / \log \mathrm{n}=\mathrm{EN} / \log 225
$$

\section{$\leq<$ Insert Table 2 here $>>$}

Therefore, a function is proposed as shown in Formula (4), although at this stage, specific relationships between the four concentration measures are still awaiting further exploration:

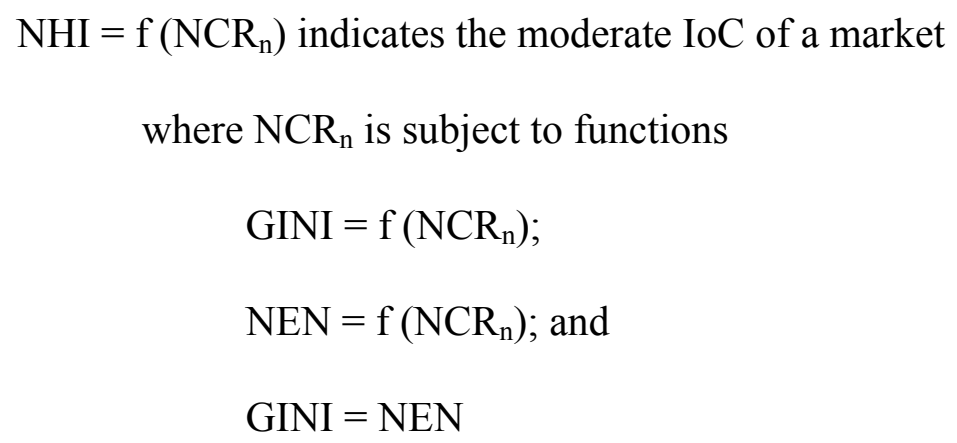

Data collection for investigating moderate IoC in the international construction market

International construction is usually referred to the construction works undertaken by companies outside their home countries. Many international construction companies have a diversity of businesses in terms of architecture, engineering, and construction. They are also able to simultaneously compete for project contracts in various countries. It is quite 
difficult, if not completely impossible, to collect data per business competition and to identify those contractors who have international businesses. Hence, data on construction activities are usually poor and erratic whatever domestic or international (Ruddock 2002).

Alternatively, the statistical data of the top 225 international contractors (TIC 225) complied by Engineering News-Record (ENR) were collected for this study owing to four major considerations. Firstly, contractors other than the TIC 225 have negligible market powers as their market shares are relatively very small. The TIC 225 are representative of the majority of overseas works undertaken by international contractors. Secondly, much of the strongest direct competition encountered by a large firm is apt to originate from competitors who are or to be in similar firm sizes (Kaplan 1980). Accordingly, competition for international construction occurs mostly among the TIC 225 themselves. Thirdly, despite some limitations in terms of country coverage, the TIC225 data have been demonstrated useful for examining the subject of international construction (Low et al. 2004; Ofori 2003). In addition, the enduring effort from ENR to publish statistical data of the TIC 225 provides a consistent series of longitude data for the present research which aims to identify the moderate $\mathrm{IoC}$ in the international construction market.

Each year, ENR deploys an individual issue to report the presence of TIC 225 in the international construction market. Using the year 2007 as an example, a typical structure of the data as reported includes ranks of the present year and past year, international revenue, total revenue and new contracts of each firm. The report also analyses market by sub-sector (e.g. buildings, waster supply project, etc.) of individual firms. The international revenue (IR) is of concern in this research. The authors tabulated the IR of the TIC 225 into the Statistics Package for Social Science (SPSS). The data in the past 28 
years from 1981 to 2008 were collected and fed into SPSS. It is mainly from the University library but Issues in years from 1981 to 1989 were collected with the kind help from colleagues in Singapore and Taiwan. From year 2001 onwards, electronic versions are available, which greatly facilitated the data collection.

\section{DATA ANALYSIS}

Annual IRs of the TIC 225 spanning from 1981 to 2008 are transferred into relative market shares to derive the indices of $\mathrm{CR}_{4}, \mathrm{EN}, \mathrm{HI}$, and GINI. The derived indices are then normalised by using Formula 1 to 3 as shown above. Results of the calculation are presented in Table 3.

\section{$\leq<$ Insert Table 3 here $>>$}

The curve regression embedded in SPSS is applied to determine the most suitable functions $\mathrm{NHI}=\mathrm{f}\left(\mathrm{NCR}_{4}\right), \mathrm{GINI}=\mathrm{f}\left(\mathrm{NCR}_{4}\right)$, and $\mathrm{NEN}=\mathrm{f}\left(\mathrm{NCR}_{4}\right)$ as pursued in Formula 4. The functional relationships between the four concentration measures are shown in Figure 2. The resultant model parameters are described separately in Table 4.

$\leq<$ Insert Figure 2 here $>>$

$\leq<$ Insert Table 4 here $>>$ 
Using the parameters in Table 4 and Formula 2 functions NHI, GINI and NEN can be rewritten as follows and described graphically in Figure 3. It can be seen that NEN and GINI intersect at a point where $\mathrm{NCR}_{4}$ is 0.2603 . According to the description as shown in Figure 1, this is the point indicating the moderate $\mathrm{IoC}$ in the international construction market. As shown in Figure 3, at this point where NCR4 is 0.2603 , a moderate IoC expressed in NHI is 0.3052 .

$$
\begin{aligned}
& N H I=0.607 \bullet\left(\frac{C R_{4}-4 / n}{1-4 / n}\right)^{2}+1.030 \bullet\left(\frac{C R_{4}-4 / n}{1-4 / n}\right)-0.004 \\
& G I N I=0.921-0.040 \bullet\left(\frac{1-4 / n}{C R_{4}-4 / n}\right) \\
& N E N=0.595 \bullet\left(\frac{C R_{4}-4 / n}{1-4 / n}\right)^{-0.189}
\end{aligned}
$$

\section{$\leq<$ Insert Figure 3 here $>>$}

Considerable researchers have pointed out the weakness of concentration measures especially in terms of data availability (McCloughan 2004; Adelman 1951; Parker 1991). Many concentration ratios are not made available in official publications, which typically include information on the size distribution of firms, as it is not permitted to disclose commercial data for individual firms (McCloughan and Abounoori 2003). Thus, researchers commonly opt for the most readily available measure, CR 4 (Wang 2004; Boyes and Smyth 1979). Compared with the equations shown in Table 1, equations 5-7 are more applicable as they are built on $\mathrm{CR}_{4}$ rather than commercial data for all individual firms. Furthermore, using these equations, it is expected to be able to detect the level of moderate concentration if only GINI equals to NEN. 


\section{FINDINGS AND DISCUSSION}

\section{Understanding international construction market by using the Moderate IoC Model}

Based on the above analysis, it can be seen that the new model can inform a moderate intensity of competition ( $\mathrm{IoC}$ ) in a given market. By synthesising existing concentration measures, the Moderate IoC Model suggests that the intersection between GINI and EN indicates that the competition within a market is moderate; the market is contestable from the perspectives of market entry barriers and winning business competition. The Moderate IoC Model also avoids the demerits of existing concentration measures. $\mathrm{CR}_{\mathrm{n}}$ is a rough measure of market concentration but calculating $\mathrm{CR}_{\mathrm{n}}$ is relatively easier in terms of data availability. $\mathrm{HI}$ is a better measure than $\mathrm{HI}$ in reflecting competition intensity, but the difficulty of collecting data for $\mathrm{HI}$ undermines its wider applicability. The shortcomings are overcome in this research by using $\mathrm{CR}_{\mathrm{n}}$ to construct $\mathrm{EN}$, GINI and $\mathrm{HI}$.

By applying 28 years' data from ENR to the Moderate IoC Model, it is found that the intensity of competition in the international construction market is moderate when normalised $\mathrm{CR}_{4}\left(\mathrm{NCR}_{4}\right)$ is 0.2603 and the indices of NHI, GINI, and NEN are 0.3052 , 0.7673 , and 0.7673 respectively. By applying the normalised indices into Formula (1) to (3), the values of $\mathrm{CR}_{4}, \mathrm{HI}$, and $\mathrm{EN}$ are derived, namely, $0.2735,0.3083$, and 1.8049 respectively. In other words, the IoC in the international market construction market is moderate when $\mathrm{CR}_{4}$ is 0.2735 and $\mathrm{HI}$ is 0.3083 . This gives a reference point against which the IoC level in the international construction market can be compared. The closer the NHI value to the point (where HI is 0.3083 ) indicated by the intersection of NEN and GINI, the more appropriate the concentration status as well as the IoC level. 
IoC as expressed in NHI over the study period 1981 to 2008 is calculated and shown in Figure 4. It can be seen that the international construction competition was relatively moderate in three years, namely 1992, 2001 and 2004. A significant variation in IoC over the study period 1981 to 2008 is also noted; the competition intensity in the international construction market during the period has exhibited a wavy trend. This does revise a view presented earlier in this paper that the competition for international construction business has been intensifying only since 2002. Actually, from 2002 to 2008 , sometimes the IoC is close to the moderate level, while others it is deviate from the level.

\section{$\leq<$ Insert Figure 4 here $>>$}

\section{Comparing the Moderate IoC Model with previous concentration studies}

To some extent, the research findings contradict previous concentration studies conducted in contexts (e.g. domestic economy) other than the international construction market. Baldwin and Gorecki (1994) claimed that an industry with $C R_{4}$ above $75 \%$ is more conducive to have a "competition problem" that undermines the role of market in resource allocation. As such, it appears that the international construction market has been good since 1981, for all the $\mathrm{CR}_{4}$ values (Table 3 ) are fairly lower than this alert level. However, according to Oster (1999), competition statuses can be classified into four groups in accordance with $\mathrm{CR}_{4}$ values, namely, highly concentrated oligopoly (1.00$0.75)$, moderately concentrated oligopoly (0.50-0.749), oligopoly (0.25-0.499), and atomism (0.00-0.249). The competition for international construction in the past twentyeight years satisfies Oster's definition of atomism, thus, the market has been overcompetitive for long time. 
Herfindahl index (HI) can be used to gauge potential adverse competitive effects imposed by a merger and market efficiency. For instance, in the United States, a postmerger $\mathrm{HI}$ below 0.1000 in a market is deemed as unconcentrated and above 0.1800 is regarded to be highly concentrated (DJFTC 1997). The larger the extent to which HI exceeds 0.1800 , the less the competition will be in the market. Therefore, it is widely accepted that those industries with $\mathrm{HI}$ values over 0.1800 are of insufficient competition (Oster 1999). However, this is not the case in the context of international construction; as suggested by the Moderate IoC model, a moderate IoC is recorded when $\mathrm{HI}$ is 0.3083 , other than 0.1800 .

The IoC in the international construction market can also be interpreted in GINI level. As suggested previously, an IoC is moderate when GINI is 0.7673 . The closer the Gini coefficient (GINI) to 1 , the less equal the distribution of firm sizes in a market, and the lower the IoC. According to this GINI rule, the moderate concentration in the international construction market should refer to a relatively unequal distribution of firm sizes, thus the competition therein is not fierce. In addition, as presented above, concentration decreases as entropy (EN) values increase. The moderate concentration of the international construction market has an entropy value of $1.8049,76.73$ percent relative to the maximum entropy (log 225). This EN level signifies a relatively low level of concentration and high level of intensity of competition.

To summarise, by comparing the Moderate IoC Model with previous concentration studies, it is apparent that the study of concentration in the international construction market necessitates a particular examination. Research findings developed in other sectors or in the area of domestic economy cannot be applied to this particular market. 
This in turn verifies the inefficiency of the existing concentration measures in investigating IoC in the international construction context.

\section{Using the Moderate IoC Model}

It has been found in this study that the Moderate IoC Model is applicable to indicate a moderate concentration (or IoC) in the international construction market. By mapping the evidence against the derived moderate concentration, it will be possible to provide contractors with advice on how they could have a better understanding of concentration situations in the international construction market. For example, it might not be good for contractors to perform international construction businesses when NHI index has been away from the moderate level, which implies that the competition in the market is too fierce.

Although the Moderate $\mathrm{IoC}$ Model is able to indicate a moderate concentration for international contractors, there is limited an individual company can do to change the competition. This is particularly true in the international construction market which is actually formulated by many individual regional parts, for example, U.S. market, Western European market, the Middle East market. Except for the market force, there is no organisation to regulate and develop a moderately concentrated international construction market. This is contrasting with the situation in some domestic economies (e.g. China) where governmental departments tend to maintain a moderate IoC by introducing some measures such as qualification system, increasing/decreasing government spending, etc.

\section{CONCLUSIONS}


A moderate concentration of market shares contributes to the efficiency of market resources allocation. By synthesising four major concentration methods, namely, concentration ratio $\left(\mathrm{CR}_{\mathrm{n}}\right)$, Herfindahl index $(\mathrm{HI})$, entropy, and Gini coefficient, a Moderate IoC Model is developed in this study for identifying moderate concentration in the international construction market. The model is superior to the existing concentration measures in several aspects. The model balances the merits and demerits of the existing concentration measures, elaborates a way for approaching moderate concentration, and is easily computable by using the market shares of the top four construction contractors.

By applying 28 years' data from ENR to the Moderate IoC Model, it is found that the IoC in the international construction market is moderate when $\mathrm{CR}_{4}$ is 0.2735 and $\mathrm{HI}$ is 0.3083 respectively. This gives a reference point against which the IoC level can be compared. The closer the HI value to the point where HI is 0.3083 , the more appropriate the concentration status as well as the IoC level. Based on this, the international construction competition was found to be relatively moderate in 1992, 2001 and 2004. The competition intensity in the international construction market during the period has exhibited a wavy trend. This revises a popular view that the international construction competition has been increasingly intensifying only since 2002 .

By comparing the Moderate IoC Model with previous concentration studies, it is found that the study of concentration in the international construction market necessitates a new examination with new approaches. Research findings developed in other sectors cannot be applied to this particular market. The Moderate IoC Model complements the existing concentration measures in investigating IoC in the international construction context. The identified moderate IoC can be a valuable reference for practitioners to understand characteristics of the international construction market; it is implied that it is good for 
contractors to compete for international construction business when the market is approaching its moderate status.

It is claimed that the HI 0.3083 can be a cut-off concentration level for the international construction market. A concentration status can be acceptable, referred to the buffer zone of concentration, even though it does not reach the ideal concentration situation. Although this study does not exactly provide the buffer zone of concentration, the HI 0.3083 is constructive and informative, as it lays a theoretical foundation for the future studies.

\section{REFERENCES}

Adelman, M.A. (1951). "The Measurement of Industrial Concentration." Review of Economics and Statistics 33(4): 269-296.

Akintoye, A. and M. Skitmore (1991). "Profitability of UK Construction Contractors." Construction Management and Economics 9(4): 311-325.

Bailey, D. and S.E. Boyle (1971). "The Optimal Measure of Concentration." Journal of the American Statistical Association 66(336): 702-706.

Bain, J.S. (1956). Barriers to New Competition, Their Character and Consequences in Manufacturing Industries. Cambridge, Harvard University Press.

Bajo, O. and R. Salas (2002). "Inequality Foundations of Concentration Measures: An Application to the Hannah-Kay Indices." Spanish Economic Review 4(4): 311316.

Baldwin, R.J. and P.K. Gorecki (1994). "Concentration and Mobility Statistics in Canada's Manufacturing Sector." Journal of Industrial Economics 42(1): 93-103. 
Ball, M., M. Farshchi and M. Grilli (2000). "Competition and the Persistence of Profits in the UK Construction Industry." Construction Management and Economics 18(7): 733-745.

Barla, P. (1999). "Market Share Instability in the US Airline Industry." Journal of Applied Business Research 15(4): 67-79.

Bengtsson, M. (1998). Climates of Competition, Harwood Academic Publishers.

Bird, K. (1999). "Concentration in Indonesian Manufacturing, 1975-93." Bulletin of Indonesian Economic Studies 35(1): 43-73.

Bonanno, G. and B. Haworth (1998). "Intensity of Competition and the Choice between Product and Process Innovation." International Journal of Industrial Organization 16(4): 495-510.

Bonardi, L. (2001). Analysis of the Relationship between Advertising, Concentration and Profitability in the U.S. Manufacturing Industry. New York, Fordham University.

Boone, J. (2001). "Intensity of Competition and the Incentive to Innovate." International Journal of Industrial Organization 19(5): 705-726.

Boyes, J.W. and J.D. Smyth (1979). "The Optimal Concentration Measure: Theory and Evidence for Canadian Manufacturing Industries." Applied Economics 11(3): 289-302.

Carlton, D.W. and J.M. Perloff (2005). Modern Industrial Organisation. New York, Pearson Addison Wesley.

Chiang, Y.H., B.S. Tang and W.Y. Leung (2001). "Market Structure of the Construction Industry in Hong Kong." Construction Management and Economics 19(7): 675687.

Davies, S.W. (1979). "Choosing between Concentration Indices: The Iso-concentration Curve." Economica 46(181): 67-75. 
DJFTC (1997). Horizontal Merger Guidelines, U.S. Department of Justice and the Federal Trade Commission.

Egghe, L. (2005). "Zipfian and Lotkaian Continuous Concentration Theory." Journal of the American Society for Information Science \& Technology 56(9): 9325-9345.

George, K.D. (1972). "Concentration and Specialization in Industry." Journal of Industrial Economics 20(2): 107-123.

Ghosh, A. (1975). "Concentration and Growth of Indian Industries, 1948- 68." Journal of Industrial Economics 23(3): 203-222.

Guth, L.A. (1971). "Advertising and Market Structure Revisited." Journal of Industrial Economics 19(2): 179-198.

Hall, M. and N. Tideman (1967). "Measures of Concentration." Journal of American Statistical Association 62(317): 162-168.

Haworth, T.C. and J.C. Reuther (1978). "Industrial Concentration and Interindustry Wage Determination." Review of Economics and Statistics 60(1): 85-95.

Horowitz, A. and I. Horowitz (1968). "Entropy, Markov Process and Competition in the Brewing Industry." Journal of Industrial Economics 16(3): 196-211.

Kaplan, A.D.H. (1980). Big Enterprise in a Competitive System, Greenwood Press.

Korkmaz, S. and J.I. Messener (2007). "Competitive Positioning and Continuity of Construction Firms in International Markets." Journal of Management in Engineering 24(4): 207-216.

Kwoka, J.E. (1981). "Does the Choice of Concentration Measure Really Matter." Journal of Industrial Economics 29(4): 445-453.

Langford, D. and S. Male (2001). Strategic Management in Construction. Blackwell Science Ltd, Berlin, Germany.

Lipczynski, J. and J. Wilson (2001). Industrial Organisation: An Analysis of Competitive Markets. Harlow, England, Pearson Education Limited. 
Loosemore, M. (1999). "International Construction Management Research: Cultural Sensitivity in Methodological Design." Construction Management and Economics 17(5): 553-561.

Low, S.P., H. Jiang and C.H.Y. Leong (2004). "A Comparative Study of Top British and Chinese International Contractors in the Global Market." Construction Management and Economics 22(7): 717-731.

McCloughan, P. (2004). "Construction Sector Concentration: Evidence from Britain." Construction Management and Economics 22(9): 979-999.

McCloughan, P. and E. Abounoori (2003). "How to Estimate Market Concentration Given Grouped Data." Applied Economics 35(8): 973-983.

Miller, R.A. (1969). "Market Structure and Industrial Performance: Relation of Profit Rates to Concentration, Advertising Intensity, and Diversity." Journal of Industrial Economics 17(2): 104-118.

Neumann, M., J. Weigand, A. Gross and M.T. Munter (2001). "Market Size, Fixed Costs and Horizontal Concentration." International Journal of Industrial Organisation 19(5): 823-840.

Ofori, G. (2003). "Frameworks for Analysing International Construction." Construction Management and Economics 21(4): 379-391.

Oster, S.M. (1999). Modern Competitive Analysis. New York, Oxford University Press.

Parker, S.C. (1991). "Significantly Concentrated Markets Theory and Evidence for the U.K." International Journal of Industrial Organization 9(4): 585-590.

Raftery, J., B. Pasadilla, Y.H. Chiang, E.C.M. Hui and B.S. Tang (1998). "Globalization and Construction Industry Development: Implications of Recent Developments in the Construction Sectors in Asia." Construction Management and Economics 16(6): 729-737. 
Ruddock, L. (2002). "Measuring the Global Construction Industry: Improving the Quality of Data." Construction Management and Economics 20(7): 553-556.

Sawyer, C.M. (1985). The Economics of Industries and Firms. London, Croom Helm.

Shepherd, W.G. (1964). "Trends of Concentration in American Manufacturing Industries." Review of Economics and Statistics 46(2): 200-212.

Shepherd, W.G. and J.M. Shepherd (2004). The Economics of Industrial Organisation. Long Grove, Illinois, Waveland Press Inc.

Shrieves, R.E. (1978). "Market Structure and Innovation: A New Perspective." Journal of Industrial Economics 26(4): 329-347.

Utton, M.A. (1970). Industrial Concentration. Harmondsworth, Middlesex, England, Penguin Books Ltd.

van Kranenburg, H. (2002). "Mobility and Market Structure in the Dutch Daily Newspaper Market Segments." Journal of Media Economics 15(2): 107-123.

Wang, D. (2004). The Chinese Construction Industry from the Perspective of Industrial Organization, North-western University.

Wenders, J.T. (1971). "Excess Capacity as a Barrier to Entry." Journal of Industrial Economics 20(1): 14-19.

White, K.R. (1976). "On the Choice of a Concentration Measure." American Business Law Journal 14(2): 235-241.

Yu, F.T.S. (2000). Entropy and Information Optics, CRC Press. 
Table 1 Models of concentration measures

\begin{tabular}{|c|c|c|c|c|}
\hline Method & Description & Model & Range $^{(a)}$ & Reference \\
\hline$C R_{n}$ & $\begin{array}{l}\text { Aggregating the market } \\
\text { shares of the } n \text { largest firms, } \\
\text { where } n \text { is usually } 4\end{array}$ & $C R_{n}=\sum_{i=1}^{n} S_{i}$ & $(4 / \mathrm{n}, 1)^{(\mathrm{b})}$ & $\begin{array}{l}\text { (Baldwin and Gorecki } \\
\text { 1994; Wang 2004) }\end{array}$ \\
\hline HI & $\begin{array}{l}\text { Accumulating the market } \\
\text { shares of all the firms by } \\
\text { weighting the corresponding } \\
\text { market sales }\end{array}$ & $H I=\sum_{i=1}^{n} S_{i}^{2}$ & $(1 / \mathrm{n}, 1)^{(\mathrm{b})}$ & $\begin{array}{l}\text { (Davies 1979; Ghosh } \\
\text { 1975) }\end{array}$ \\
\hline$E N$ & $\begin{array}{l}\text { Measuring the degree of } \\
\text { disorder, uncertainty, or } \\
\text { randomness to reflect } \\
\text { competition intensity }\end{array}$ & $E N=\sum_{i=1}^{n} S_{i} \log \left(1 / S_{i}\right)$ & $(0, \log n)$ & $\begin{array}{l}\text { (Sawyer 1985; Davies } \\
\text { 1979) }\end{array}$ \\
\hline GINI & $\begin{array}{l}\text { Measuring the extent to } \\
\text { which businesses in a market } \\
\text { are unequal in firm size } \\
\text { distribution }\end{array}$ & $G C=\frac{n+1}{n-1}-\frac{2}{n(n-1) \mu} \cdot \sum_{i=1}^{n}\left(N_{i} S_{i}\right)$ & $(0,1)$ & $\begin{array}{l}\text { (Ghosh 1975; Guth } \\
\text { 1971; White 1976) }\end{array}$ \\
\hline
\end{tabular}

Note: $S_{i}$, firm $i$ 's market share; $n$, firm number; $N_{i}$, the rank of firm $i ; \mu$, mean market share of all firms. (a) When $n$ is very large, the ranges of both $\mathrm{CR}_{\mathrm{n}}$ and $\mathrm{HI}$ will be $(0,1)$.

Table 2 Interrelationships between the four concentration measures

\begin{tabular}{|c|c|c|c|}
\hline & & $\begin{array}{l}\text { Competition } \\
\text { Intensity }\end{array}$ & $\mathrm{CR}_{\mathrm{n}}$ \\
\hline \multicolumn{4}{|c|}{ Direction } \\
\hline $\mathrm{HI}_{\mathrm{n}}$ & $\uparrow$ & $\downarrow$ & $\uparrow$ \\
\hline GINI & $\uparrow$ & $\downarrow$ & $\uparrow$ \\
\hline EN & $\uparrow$ & $\uparrow$ & $\downarrow$ \\
\hline
\end{tabular}


Table 3 Concentration indices for international construction business

\begin{tabular}{llllllll}
\hline Year & $\mathrm{CR}_{4}$ & $\mathrm{EN}$ & $\mathrm{HI}$ & $\mathrm{GINI}$ & $\mathrm{NCR} 4$ & $\mathrm{NEN}$ & $\mathrm{NHI}$ \\
\hline 1981 & .2334 & 1.9569 & .2281 & .6676 & .2196 & .8319 & .2247 \\
1982 & .1543 & 2.0563 & .1509 & .5965 & .1390 & .8742 & .1471 \\
1983 & .1491 & 2.0417 & .1511 & .6165 & .1337 & .8680 & .1473 \\
1984 & .2223 & 2.0068 & .2031 & .6246 & .2082 & .8532 & .1996 \\
1985 & .2381 & 1.9429 & .2563 & .6689 & .2243 & .8260 & .2529 \\
1986 & .2195 & 1.9502 & .2170 & .6782 & .2054 & .8291 & .2135 \\
1987 & .1967 & 1.9877 & .1911 & .6538 & .1822 & .8450 & .1875 \\
1988 & .1508 & 2.0514 & .1450 & .6140 & .1354 & .8721 & .1412 \\
1989 & .1896 & 1.9700 & .1912 & .6696 & .1749 & .8375 & .1875 \\
1990 & .2111 & 1.8746 & .2352 & .7392 & .1968 & .7970 & .2318 \\
1991 & .2026 & 1.8856 & .2283 & .7367 & .1882 & .8016 & .2249 \\
1992 & .2731 & 1.7934 & .3043 & .7778 & .2600 & .7624 & .3012 \\
1993 & .3132 & 1.7661 & .3514 & .7838 & .3007 & .7508 & .3485 \\
1994 & .2494 & 1.8432 & .2657 & .7544 & .2358 & .7836 & .2624 \\
1995 & .1904 & 1.9559 & .1915 & .6912 & .1757 & .8315 & .1879 \\
1996 & .1638 & 1.9635 & .1742 & .6913 & .1487 & .8348 & .1705 \\
1997 & .1766 & 1.9484 & .1842 & .7008 & .1617 & .8283 & .1806 \\
1998 & .2121 & 1.9015 & .2175 & .7268 & .1978 & .8084 & .2140 \\
1999 & .1845 & 1.9179 & .2016 & .7179 & .1697 & .8154 & .1981 \\
2000 & .2104 & 1.8419 & .2428 & .7634 & .1961 & .7831 & .2394 \\
2001 & .2664 & 1.7850 & .3042 & .7838 & .2531 & .7589 & .3011 \\
2002 & .3144 & 1.7582 & .3700 & .7861 & .3020 & .7475 & .3672 \\
2003 & .2997 & 1.7586 & .3424 & .7936 & .2870 & .7476 & .3395 \\
2004 & .2607 & 1.7695 & .3118 & .7900 & .2473 & .7523 & .3087 \\
2005 & .2573 & 1.7897 & .3006 & .7797 & .2439 & .7609 & .2974 \\
2006 & .2409 & 1.8144 & .2842 & .7653 & .2271 & .7714 & .2810 \\
2007 & .2309 & 1.8499 & .2619 & .7476 & .2169 & .7865 & .2586 \\
2008 & .2020 & 1.8909 & .2291 & .7262 & .1876 & .8039 & .2257 \\
\hline & & & & & & &
\end{tabular}


Table 4 Model summary and parameter estimates

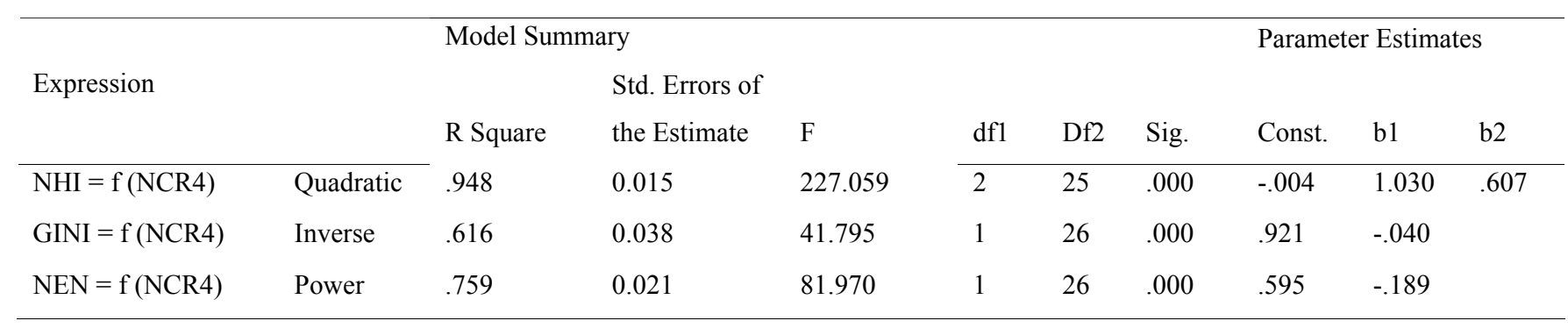

The independent variable is $\mathrm{NCR}_{4}$. 


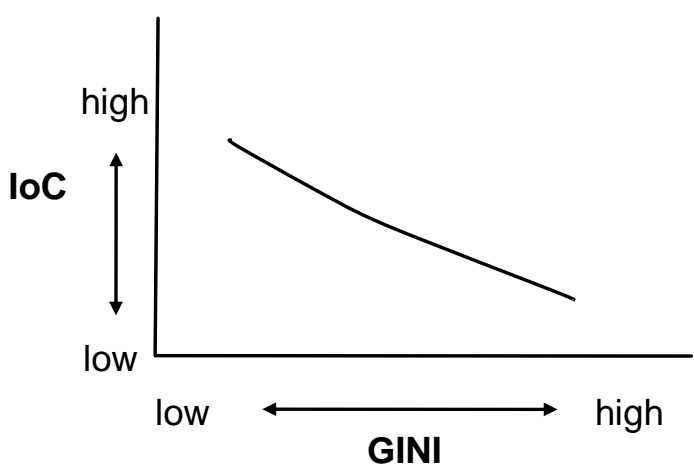

An increase in GINI level suggests the dominance of a few largest firms in the market and larger market entry barriers to potential competitors.
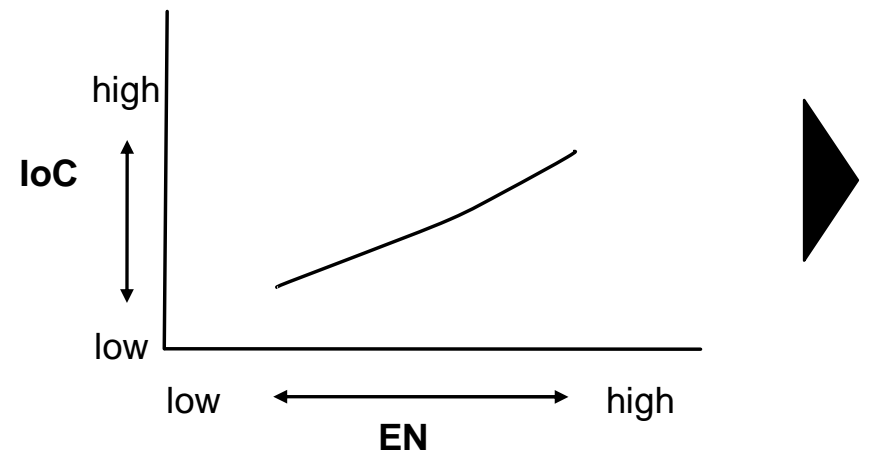

An increase in EN level suggests larger uncertainty of winning business competition among the incumbent.
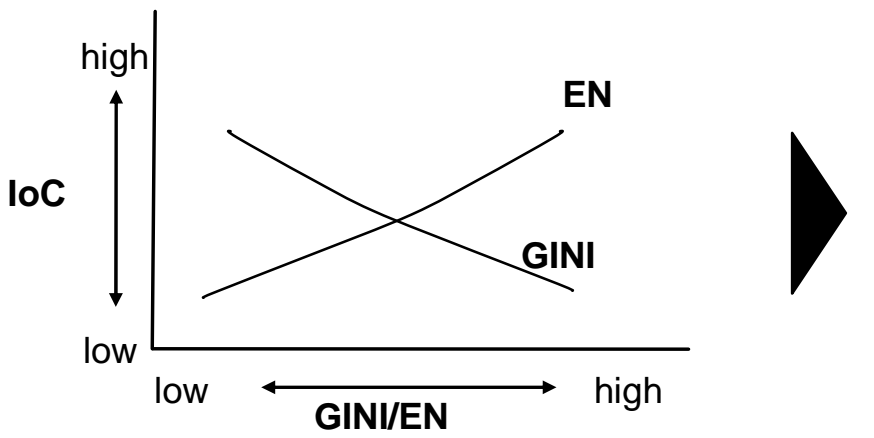

The intersection indicates the market is contestable from the perspectives of market entry barriers and winning business competition

Figure 1 Moderate level of IoC 


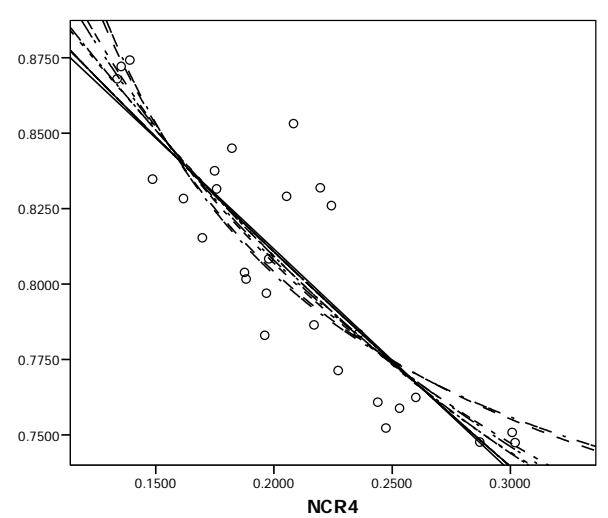

(a) NEN vs. $\mathrm{NCR}_{4}$
GINI

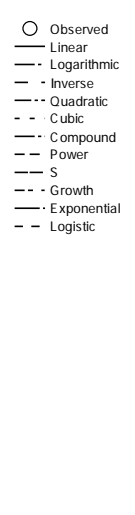

Figure 2 Functional relationships between the four concentration measures

Note: Linear, logarithmic, inverse, quadratic, cubic, compound, power, S, growth, exponential, and logistic models are compared for the choice of the best function forms.

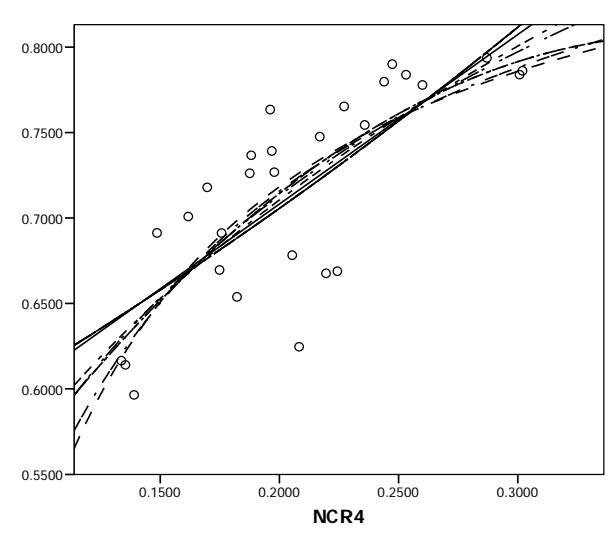

(b) GINI vs. NCR
NHI

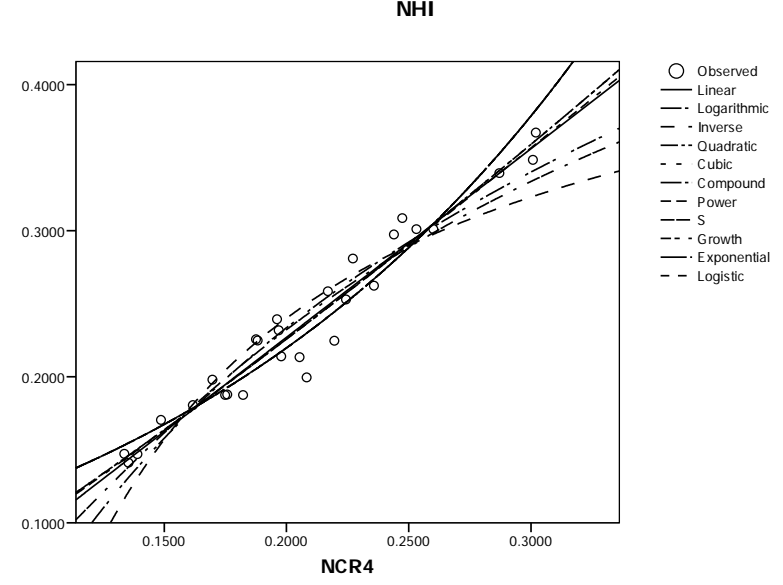

(c) $\mathrm{NHI}$ vs. $\mathrm{NCR}_{4}$

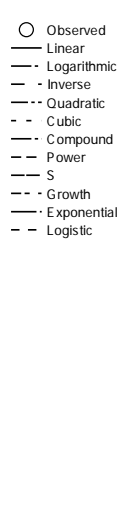




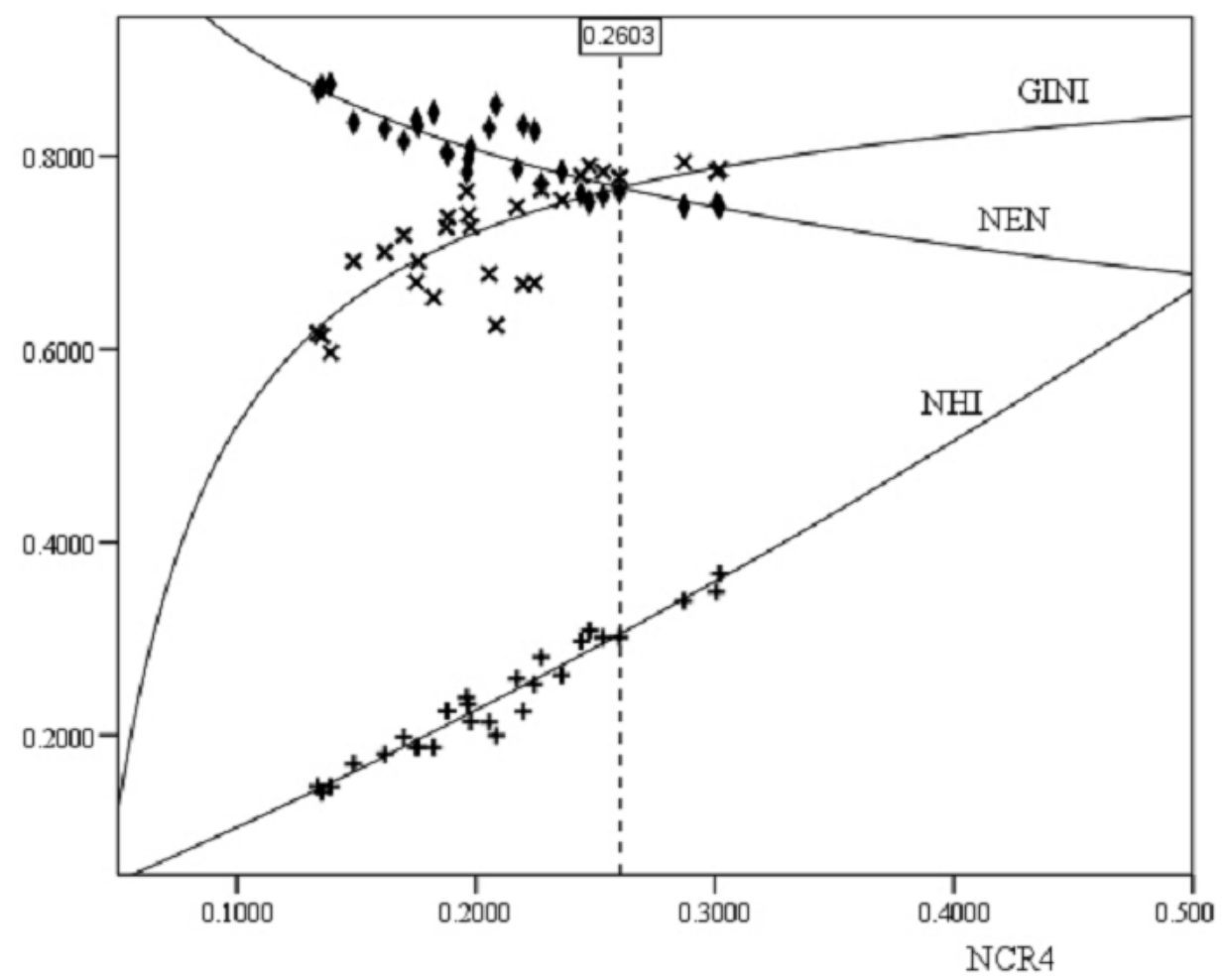

Figure 3 Moderate IoC in the international construction market 


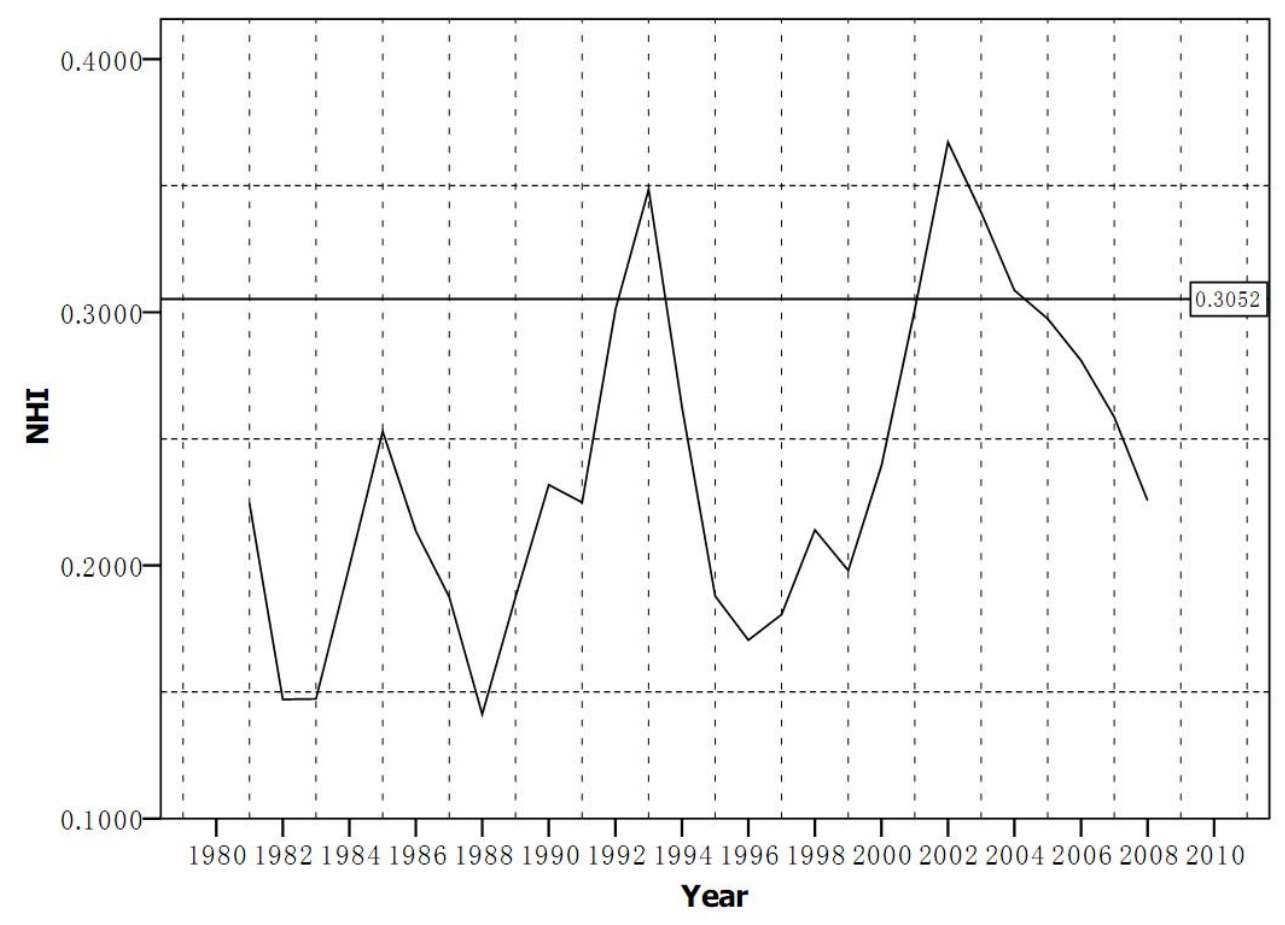

Figure 4 Annual NHI in the international construction market (1981-2008) 